DOI: $10.19195 / 0137-1134.107 .12$

\title{
MARIA SIEMASZKIEWICZ
}

Uniwersytet Wrocławski

\section{ROZPORZĄDZENIE EIDAS — NOWE RAMY PRAWNE W ZAKRESIE IDENTYFIKACJI ELEKTRONICZNEJ I USŁUG ZAUFANIA W UNII EUROPEJSKIEJ}

\section{WPROWADZENIE}

Jednym z podstawowych celów Unii Europejskiej w zakresie tworzenia jednolitego rynku europejskiego jest już od wielu lat ustanowienie homogenicznych, wspólnych wszystkim państwom członkowskim ram prawych dotyczących komunikacji elektronicznej. Zadanie to początkowo realizowane było na poziomie Unii Europejskiej jedynie fragmentarycznie m.in. przez dyrektywę 99/93 o podpisie elektronicznym ${ }^{1}$. Jej celem była harmonizacja przepisów dotyczących podpisów elektronicznych oraz uznawania podmiotów świadczących usługi certyfikacyjne, a w konsekwencji ułatwienie korzystania z e-podpisów oraz pomoc $\mathrm{w}$ doprowadzeniu do ich prawnego uznania we wszystkich krajach Unii Europejskiej. Z czasem okazało się, że europejski rynek podpisów elektronicznych nie może rozwijać się swobodnie ze względu na brak interoperacyjności w skali całej Unii Europejskiej (dyrektywa 99/93 nie wprowadzała odpowiednich przepisów dotyczących kwestii transgranicznych i międzysektorowych, które pozwoliłyby na łatwe i bezpieczne transakcje elektroniczne, w które zaangażowane byłyby publiczne lub prywatne podmioty z różnych państw członkowskich). W efekcie w ciągu piętnastu lat obowiązywania dyrektywy 99/93 nie odnotowano oczekiwanego nasycenia rynku podpisów elektronicznych ${ }^{2}$. Sytuacja ta poskutkowała koniecznością podjęcia nowej inicjatywy legislacyjnej przez prawodawcę unijnego. Efektem tych prac jest niedawne uchwalenie rozporządzenia $910 / 2014^{3}$, zwanego rozporządzeniem

1 Dyrektywa Parlamentu Europejskiego i Rady 1999/93/WE z dnia 13 grudnia 1999 r. w sprawie wspólnotowych ram w zakresie podpisów elektronicznych (Dz. Urz. UE L 12 z 19.01.2000, s. 10-12), dalej: dyrektywa 99/93 lub dyrektywa o podpisie elektronicznym.

2 D. Wachnik, Rozporzadzenie eIDAS - na pograniczu technologii i prawa, Elektronika 2014, nr 2, s. 42.

3 Rozporządzenie Parlamentu Europejskiej i Rady (UE) 910/2014 z dnia 23 lipca 2014 r. w sprawie identyfikacji elektronicznej i usług zaufania w odniesieniu do transakcji elektronicznych 
eIDAS ${ }^{4}$, którego przepisy zaczną być stosowane, co do zasady, z dniem 1 lipca 2016 roku.

Zadaniem rozporządzenia eIDAS jest wprowadzenie jednolitych dla całej Unii Europejskiej przepisów dotyczących identyfikacji elektronicznej oraz tzw. usług zaufania. Stanowi to istotny krok w stronę budowy jednolitego rynku cyfrowego w Unii Europejskiej, którego celem jest usunięcie krajowych ograniczeń dotyczących transakcji internetowych. Strategia jednolitego rynku cyfrowego opiera się na trzech filarach obejmujących zapewnienie konsumentom i przedsiębiorstwom łatwiejszego dostępu do towarów i usług cyfrowych w całej Europie, tworzenie odpowiednich warunków rozwoju sieci i usług cyfrowych oraz maksymalizację wzrostu gospodarki cyfrowej ${ }^{5}$. Zadania te realizuje m.in. rozporządzenie eIDAS, które ustanawia nowy system bezpiecznych interakcji elektronicznych między obywatelami, przedsiębiorstwami i władzami publicznymi w całej UE. Celem uchylenia dyrektywy 99/93 i zastąpienia jej rozporządzeniem jest zwiększenie zaufania wskazanych podmiotów do transakcji elektronicznych na rynku wewnętrznym zarówno w zakresie publicznych, jak i prywatnych usług online ${ }^{6}$. Rozporządzenie eIDAS nie odcina się jednak od osiągnięć wypracowanych w oparciu o dyrektywę o podpisie elektronicznym, zamiast tego umacnia niektóre rozwiązania dyrektywy, a także poszerza zakres przedmiotowy, obierając sobie za cel rozwój wzajemnego, transgranicznego uznawania instrumentów w zakresie identyfikacji elektronicznej, dokumentów elektronicznych i usług zaufania.

Czy rozporządzenie eIDAS faktycznie przyczyni się do zwiększenia bezpieczeństwa internetowej aktywności Europejczyków, i to zarówno w ramach transakcji dokonywanych przez Internet, jak również w ich kontaktach z władzami publicznymi? Czy zniesienie barier w stosowaniu środków identyfikacji elektronicznej w Unii Europejskiej osiągnie swój cel w postaci intensywnego rozwoju gospodarki cyfrowej? Czy rozwiązania przewidziane przez rozporządzenie eIDAS trafnie wpasują się w potrzeby obywateli Unii Europejskiej?

na rynku wewnętrznym oraz uchylające dyrektywę 1999/93/WE (Dz. Urz. UE L 257 z dnia 28 sierpnia 2014, s. 73-114), dalej: rozporządzenie eIDAS lub rozporządzenie.

${ }^{4}$ Projekt rozporządzenia w sprawie identyfikacji elektronicznej został opublikowany przez Komisję Europejską w dniu 4 czerwca 2012 r. Prace nad projektem trwały jedynie 2 lata. Już w lutym 2014 r. między Parlamentem Europejskim, Komisją Europejską i Radą zawarte zostało porozumienie co do treści przyszłego rozporządzenia. Finalnie za projektem rozporządzenia głosowało 534 europosłów, przy 73 głosach przeciw i 7 wstrzymujących się — zob. C. Cuijpers, J. Schroers, eIDAS as guideline for the development of a pan European eID framework in FutureID, Open Identity Summit 2014, November 4-6, 2014, s. 5; https://lirias.kuleuven.be/bitstream/123456789/470230/2/OID +2014+paper+Jessica+Colette+v_final1.pdf (dostęp: 20.03.2016).

5 Komunikat Komisji Europejskiej pt. „Strategia jednolitego rynku cyfrowego dla Europy” z dnia 6 maja 2015 r. (COM(2015) 192 final) https://mac.gov.pl/files/komunikat_komisji_europejskiej_-_strategia_jednolitego_rynku_cyfrowego.pdf (dostęp: 20.03.2016).

${ }^{6}$ Zob. motyw 2 preambuły rozporządzenia. 


\section{WERYFIKACJA SKUTECZNOŚCI DYREKTYWY 99/93}

Rozporządzenie eIDAS, w przeciwieństwie do dyrektywy 99/93, ma za zadanie unifikować, a nie jedynie harmonizować przepisy związane z problematyką identyfikacji elektronicznej i usług zaufania ${ }^{7}$. Ustawodawca unijny zdecydował się na zastąpienie dyrektywy (a więc aktu wymagającego wdrożenia do krajowych porządków prawnych w procesie transpozycji) rozporządzeniem, które jest bezpośrednio stosowane we wszystkich państwach członkowskich ${ }^{8}$. Oznacza to, że przepisy rozporządzenia eIDAS nie będą wymagały implementacji do krajowych systemów prawa, jak również nie pozostawią organom krajowym swobody w zakresie formy i środków służących realizacji celów wskazanych w rozporządzeniu.

Na gruncie obowiązywania dyrektywy 99/93 poszczególne kraje członkowskie Unii Europejskiej wypracowały własne systemy identyfikacji elektronicznej. Obywatele Unii Europejskiej nie byli jednak uprawnieni do korzystania z krajowych metod e-identyfikacji w celu uwierzytelnienia w innym państwie członkowskim, ponieważ metody te nie były automatycznie uznawane na terytorium całej Unii Europejskiej. Taka sytuacja skutkowała stworzeniem niepotrzebnych barier w działalności gospodarczej unijnych przedsiębiorców oraz życiu codziennym wielu obywateli Unii Europejskiej, a w szczególności trudnościami w relacjach z organami publicznymi poszczególnych krajów UE. W jawny sposób kłóciło się to $\mathrm{z}$ ideą jednolitego rynku cyfrowego w ramach całej Unii Europejskiej i uniemożliwiało przedsiębiorcom pełną aktywność na rynku wewnętrznym. Zrodziło to potrzebę wzajemnego uznawania środków identyfikacji elektronicznej na terytorium Unii Europejskiej, a tym samym konieczność odejścia od rozwiązań dyrektywy 99/93 na rzecz dalej idącej interoperacyjności.

Podkreślić należy, że chociaż celem rozporządzenia jest zniesienie istniejących barier w transgranicznym stosowaniu środków identyfikacji elektronicznej, to ustawodawca unijny nie zdecydował się nigdy na wprowadzenie wspólnego europejskiego systemu e-identyfikacji. Zamiast tego wyraźnie podkreślił, że jego intencją nie jest ingerowanie w systemy zarządzania tożsamością elektroniczną i powiązaną z nimi infrastrukturę, już ustanowione w państwach członkowskich ${ }^{9}$. Nie zmienia to jednak faktu, że państwa członkowskie zmuszone będą uchylić przepisy krajowe wydane w procesie implementacji dyrektywy 99/93 ${ }^{10} \mathrm{i}$ od tej

7 Wyraźnie zauważalna w ostatnim czasie jest tendencja ustawodawcy unijnego do unifikacji (zamiast harmonizacji) przepisów dotyczących e-usług (P.P. Polański, Towards the single digital market for e-identification and trust services, „Computer Law \& Security Review” 31, 2015, nr 6, s. 774).

8 Początkowo rozważano możliwość nowelizacji przepisów dyrektywy 99/93, jednak unifikacja tego obszaru przez rozporządzenie unijne uznana została za bardziej efektywne narzędzie regulacji identyfikacji elektronicznej i usług zaufania (D. Wachnik, op. cit., s. 42).

9 Zob. motyw 12 preambuly rozporządzenia.

10 W przypadku Polski uchylona powinna zostać ustawa z dnia 18 września 2001 r. o podpisie elektronicznym (Dz.U. 2013, poz. 262 ze zm.) 
pory stosować bezpośrednio rozporządzenie eIDAS ${ }^{11}$, które może zostać jedynie uzupełnione odpowiednim ustawodawstwem krajowym ${ }^{12}$.

Jednym z zarzutów kierowanych pod adresem dyrektywy 99/93 był jej ograniczony zakres przedmiotowy, albowiem skupiała się ona jedynie na problematyce podpisów elektronicznych, pomijając inne ważne usługi zaufania, a także problematykę identyfikacji elektronicznej. Ustawodawca unijny, tworząc rozporządzenie eIDAS, wsłuchał się w głosy krytyki i poszerzył zakres przedmiotowy regulacji, obejmując nim również m.in. elektroniczne pieczęcie, elektroniczne znaczniki czasu, usługi rejestrowanego doręczenia elektronicznego oraz uwierzytelnianie witryn internetowych ${ }^{13}$.

\section{IDENTYFIKACJA ELEKTRONICZNA}

Niemożliwe jest przeprowadzenie dalszych rozważań dotyczących rozporządzenia eIDAS bez sprecyzowania, co ustawodawca unijny rozumie przez pojęcie identyfikacji elektronicznej (eID). Zgodnie z art. 3 pkt 1 rozporządzenia identyfikacja elektroniczna jest ,procesem używania danych w postaci elektronicznej identyfikujących osobę, unikalnie reprezentujących osobę fizyczną lub prawną, lub też osobę fizyczną reprezentującą osobę prawną ${ }^{14 "}$. Z powyższego wynika, że ustawodawca unijny przewiduje możliwość weryfikacji tożsamości również osób prawnych. Środek identyfikacji elektronicznej oznacza zaś „materialną lub niematerialną jednostkę zawierającą dane identyfikujące osobę i używaną do celów uwierzytelniania dla usługi online" 15 . W uproszczeniu chodzi tutaj o metodę, instrument lub narzędzie potrzebne do tego, aby być elektronicznie rozpoznawalnym.

11 P.P. Polański, op. cit., s. 774.

12 Rozpoczęcie stosowania rozporządzenia eIDAS będzie wymagało dostosowania krajowych uregulowań o charakterze ustawowym. W Polsce przygotowywany jest obecnie projekt ustawy o usługach zaufania, elektronicznej identyfikacji i zmianie niektórych ustaw. Projekt ustawy ma regulować m.in. kwestię nadzoru, zawieszania certyfikatów, zakończenia działalności przez usługodawców i systemu kar. Planowana ustawa ma również dokonać niezbędnych zmian terminologicznych i prawnych w innych aktach prawnych celem dostosowania się do regulacji rozporządzenia i zapewnienia spójności systemu prawa. Planowany termin przyjęcia projektu przez Radę Ministrów — I/II kwartał 2016 r., http://bip.kprm.gov.pl/kpr/bip-rady-ministrow/prace-legislacyjne-rm-i/prace-legislacyjne-rady/wykaz-prac-legislacyjny/r2244,Projekt-ustawy-o-uslugach-zaufania-elektronicznej-identyfikacjii-zmianie-niekto.html (dostęp: 20.03.2016).

13 C. Cuijpers, J. Schroers, op. cit., s. 6.

14 Process of using person identification data in electronic form uniquely representing either a natural or legal person, or a natural person representing a legal person (art. 3 pkt 1 rozporządzenia eIDAS).

15 Art. 3 pkt 2 rozporządzenia. 
Podstawową zasadą wprowadzoną przez rozporządzenie eIDAS jest obowiązek wzajemnego uznawania środków identyfikacji elektronicznej ${ }^{16}$. W wyniku realizacji tego obowiązku wszystkie kraje członkowskie Unii Europejskiej będą zobowiązane do wzajemnej akceptacji i uznawalności systemów e-identyfikacji pochodzących z pozostałych państw członkowskich (przykładowo obywatel jednego państwa członkowskiego będzie mógł załatwić sprawę administracyjną przed organami administracji publicznej innego państwa członkowskiego, nie wychodząc z domu, a posługując się np. swoim elektronicznym dowodem osobistym). Każdy kraj członkowski Unii Europejskiej na przestrzeni ostatnich kilkunastu lat samodzielnie tworzył własne systemy identyfikacji elektronicznej. Z uwagi na powyższe znacznie różnią się one między sobą, przedstawiając bardzo szeroki wachlarz instrumentów e-identyfikacji (od estońskiego systemu elektronicznych dowodów osobistych po polski ePUAP ${ }^{17}$ oferujący darmowy podpis elektroniczny dla każdego obywatela — tzw. profil zaufany).

Wzajemne uznawanie krajowych systemów identyfikacji elektronicznej nie jest jednak bezwarunkowe. Istnienie po stronie krajów Unii Europejskiej obowiązku uznawania systemów e-identyfikacji pochodzących z innych państw członkowskich zależne jest od spełnienia pewnych wymogów. Po pierwsze, dany środek identyfikacji elektronicznej musi spełniać warunki wskazane w rozporządzeniu eIDAS. Po drugie zaś, państwo członkowskie musi dopełnić obowiązku notyfikacji danego środka, a notyfikacja ta powinna zostać opublikowana w Dzienniku Urzędowym Unii Europejskiej ${ }^{18}$. Podkreślić w tym miejscu należy, że państwom członkowskim pozostawiona została pełna dowolność co to tego, czy notyfikować Komisji wszystkie, niektóre lub żaden z krajowych systemów identyfikacji elektronicznej. Zadaniem rozporządzenia jest bowiem jedynie ustanowienie warunków dotyczących tego, jakie środki identyfikacji elektronicznej mogą być wzajemnie uznawane i w jaki sposób notyfikować systemy identyfikacji elektronicznej.

Zgodnie z art. 8 rozporządzenia każdy system identyfikacji elektronicznej, który jest notyfikowany Komisji Europejskiej, musi określać poziom bezpieczeństwa środka identyfikacji w ramach tego systemu wydawanego (niski, średni lub wysoki ${ }^{19}$ ). Poziomy bezpieczeństwa mają za zadanie oznaczenie stopnia, w jakim można mieć zaufanie do danego środka identyfikacji w zakresie ustalania tożsamości danej osoby (czy możemy mieć pełne zaufanie, czy też powinno być ono

16 W obszarze wzajemnego uznawania elektronicznej identyfikacji Komisja Europejska w ciągu kilku ostatnich lat realizowała duże projekty pilotażowe (STORK i STORK2).

17 Elektroniczna Platforma Usług Administracji Publicznej (ogólnopolska platforma teleinformatyczna służąca komunikacji obywateli z organami administracji publicznej online).

18 Zob. art. 9 rozporządzenia.

19 Znaczenie poszczególnych poziomów bezpieczeństwa wytłumaczone zostało w art. 8 ust. 2 lit. a-c rozporządzenia. 
ograniczone $)^{20}$. Omawiana zasada wzajemnego uznawania systemów identyfikacji elektronicznej obowiązuje jedynie do tych środków, których poziom bezpieczeństwa tożsamości jest równy poziomowi wymaganemu w odniesieniu do danej usługi online lub wyższy od tego poziomu. Co więcej, obowiązek ten ma zastosowanie tylko wtedy, gdy poziom bezpieczeństwa środka identyfikacji elektronicznej stosowanego przez odpowiedni podmiot sektora publicznego odpowiada średniemu lub wysokiemu poziomowi bezpieczeństwa ${ }^{21}$.

Dla porządku wskazać należy, że stosowanie przepisów rozporządzenia eIDAS dotyczących obszaru identyfikacji elektronicznej odroczone zostało do września 2018 roku, a podyktowane jest to koniecznością dostosowania do nowych wymogów zarówno prawodawstw poszczególnych państw członkowskich, jak i systemów administracji publicznej. Do dnia 29 września 2018 roku wzajemne uznawanie systemów e-identyfikacji będzie oparte na zasadzie dobrowolności, po tej dacie będzie to bezwzględny obowiązek wszystkich państw członkowskich. Pamiętać należy, że wzajemne uznawanie systemów e-identyfikacji w całej Unii Europejskiej musi pociągać za sobą nie tylko współdziałanie w sferze prawnej, lecz również współpracę techniczną, których celem będzie stworzenie prawidłowo funkcjonującej sieci niejednolitych, a jedynie połączonych z sobą systemów identyfikacji ${ }^{22}$. Oznacza to, że krajowe systemy identyfikacji elektronicznej (po przejściu procedury notyfikacji) mają wykazywać się cechą interoperacyjności ${ }^{23}$. W tym celu rozporządzenie eIDAS ustanowiło ramy interoperacyjności, które mają spełniać następujące kryteria ${ }^{24}$ :

— mają być neutralne pod względem technologicznym i nie dyskryminować żadnych konkretnych krajowych rozwiązań technicznych w zakresie identyfikacji elektronicznej w danym państwie członkowskim,

20 Przy ustalaniu poziomu bezpieczeństwa bierze się pod uwagę m.in. procedurę zgłaszania tożsamości i jej weryfikacji, stosowane zabezpieczenia, charakter jednostki wydającej środek identyfikacji elektronicznej oraz samą metodę wydawania takiego środka.

21 Zgodnie z motywem 15 preambuły do rozporządzenia państwa członkowskie powinny mieć swobodę w zakresie uznawania środków identyfikacji elektronicznej charakteryzujących się niższymi poziomami bezpieczeństwa.

22 Zgodnie z rozporządzeniem współpraca między państwami członkowskimi obejmuje m.in. wymianę informacji, doświadczeń i dobrych praktyk w zakresie systemów identyfikacji elektronicznej, a w szczególności wymogów technicznych związanych z interoperacyjnością i poziomami bezpieczeństwa, wzajemną ocenę systemów identyfikacji elektronicznej objętych rozporządzeniem oraz analizę istotnych zmian w sytuacji w sektorze identyfikacji elektronicznej (zob. art. 12 ust. 5 rozporządzenia).

23 Wśród przedstawicieli literatury przedmiotu pojawiło się już jednak stanowisko, że regulacja rozporządzenia eIDAS jest niewystarczająco szczegółowa, aby zapewnić interoperacyjność tych rozwiązań w praktyce (zob. P. Parycek, G.M. Lentner, Electronic identity (eID) and electronic signature (eSig) for eGovernment services - a comparative legal study, „Transforming Government: People, Process and Policy" 10, 2016, nr 1, s. 6).

24 Zob. art. 12 ust. 3 rozporządzenia. 
— mają być, w miarę możliwości, zgodne z europejskimi i międzynarodowymi standardami w tym zakresie,

— mają ułatwiać wdrożenie zasady uwzględniania ochrony prywatności już $\mathrm{w}$ fazie projektowania,

— mają zapewniać, aby dane osobowe były przetwarzane zgodnie z dyrektywą 95/46/WE ${ }^{25}$.

\section{ODPOWIEDZIALNOŚĆ W ZAKRESIE IDENTYFIKACJI ELEKTRONICZNEJ}

Po wypełnieniu przez państwo członkowskie warunków zgłoszenia krajowego systemu identyfikacji elektronicznej (zawierającego m.in. opis notyfikowanego systemu e-identyfikacji oraz informację na temat poziomu jego bezpieczeństwa $^{26}$ ) i opublikowaniu go w Dzienniku Urzędowym Unii Europejskiej państwo członkowskie staje się odpowiedzialne za bezpieczeństwo notyfikowanego systemu e-identyfikacji. Zgodnie z art. 10 ust. 1 rozporządzenia eIDAS w przypadku naruszenia lub częściowej kompromitacji notyfikowanego systemu identyfikacji elektronicznej albo uwierzytelnienia, o którym mowa w art. 7 lit. f) rozporządze$n^{2}{ }^{27}$, mających wpływ na wiarygodność transgranicznego uwierzytelnienia tego systemu, notyfikujące państwo członkowskie zobowiązane jest do bezzwłocznego zawieszenia lub unieważnienia tego transgranicznego uwierzytelniania lub skompromitowanych części oraz do powiadomienia o tym fakcie pozostałe państwa członkowskie, a także Komisję Europejską. Każde państwo członkowskie ma bezwzględny obowiązek jak najszybszego wyeliminowania naruszenia bezpieczeństwa swojego systemu e-identyfikacji. Po usunięciu naruszenia państwo członkowskie zobowiązane jest do przywrócenia transgranicznego uwierzytelniania i powiadomienia o tym bez zbędnej zwłoki pozostałe państwa członkowskie oraz Komisję Europejską. Jeżeli zaś państwo członkowskie nie wykona obowiązku usunięcia naruszenia bezpieczeństwa w ciągu trzech miesięcy od zawieszenia lub unieważnienia, taki system identyfikacji elektronicznej należy całkowicie wy-

25 Dyrektywa 95/46/WE Parlamentu Europejskiego i Rady z dnia 24 października 1995 r. w sprawie ochrony osób fizycznych w zakresie przetwarzania danych osobowych i swobodnego przepływu tych danych (Dz. Urz. UE L 281 z dnia 23 listopada 1995 r., s. 31-50).

26 Szczegółowe wymagania dotyczące systemów identyfikacji elektronicznej kwalifikujących się do notyfikowania oraz samej notyfikacji opisane zostały odpowiednio w art. 7 i art. 9 rozporządzenia.

27 Zgodnie z art. 7 lit. f) rozporządzenia notyfikujące państwo członkowskie zapewnia dostępność uwierzytelniania online, tak aby każda strona ufająca mająca siedzibę na terytorium innego państwa członkowskiego mogła potwierdzić dane identyfikujące osobę otrzymane w postaci elektronicznej. Zgodnie zaś z art. 3 pkt 5 rozporządzenia „uwierzytelnianie” oznacza proces elektroniczny, który umożliwia identyfikację elektroniczną osoby fizycznej lub prawnej, lub potwierdzenie pochodzenia oraz integralności weryfikowanych danych w postaci elektronicznej; 
cofać i powiadomić o tym fakcie pozostałe państwa członkowskie oraz Komisję Europejską.

Państwa członkowskie nie są jedynymi podmiotami odpowiedzialnymi za szkody wyrządzone w związku z realizacją zadań dotyczących e-identyfikacji. W przypadku wyrządzenia szkody osobie fizycznej lub prawnej w związku z niewypełnieniem obowiązków określonych w rozporządzeniu eIDAS odpowiedzialność ponoszą notyfikujący dany system e-identyfikacji kraj członkowski, strona wydająca środek identyfikacji elektronicznej oraz strona zarządzająca procedurą uwierzytelniania.

Zgodnie z art. 11 ust. 1 rozporządzenia notyfikujące państwo członkowskie jest odpowiedzialne za szkody wyrządzone niewypełnieniem swoich obowiązków na mocy art. 7 lit. d) i f) ${ }^{28}$ w ramach transgranicznej transakcji. Oznacza to, że dany kraj członkowski Unii Europejskiej ponosi odpowiedzialność za powyższe szkody w przypadku każdej transakcji prowadzonej między krajami UE niezależnie od tego, czy szkoda została wyrządzona w sposób zamierzony, czy też z powodu zaniedbania. Za niewypełnienie obowiązku, o którym mowa w art. 7 lit. e) ${ }^{29}, w$ ramach transgranicznej transakcji odpowiedzialność za szkodę (na tych samych warunkach) ponosi strona wydająca dany środek identyfikacji elektronicznej. W przypadku szkody wyrządzonej niezapewnieniem poprawnego przebiegu procesu uwierzytelniania odpowiedzialność ponosi strona przeprowadzająca tę procedurę.

Z powyższego wynika, że państwa członkowskie nie są jedynymi podmiotami ponoszącymi odpowiedzialność za niewypełnienie obowiązków związanych z e-identyfikacją określonych w rozporządzeniu. Do przypisania odpowiedzialności sądy krajowe stosować będą krajowe przepisy dotyczące odpowiedzialności; rozporządzenie nie narusza przepisów krajowych w tym zakresie (dotyczących np. definicji odszkodowania, rozkładu ciężaru dowodu lub odpowiednich regulacji proceduralnych).

28 Art. 7 lit. d) stanowi, że „notyfikujące państwo członkowskie zapewnia, aby dane identyfikujące osobę unikalnie reprezentujące daną osobę przyporządkowane były [...] osobie fizycznej lub prawnej, o której mowa w art. 3 pkt 1, w momencie wydania środka identyfikacji elektronicznej w ramach tego systemu”. Zgodnie zaś z art. 7 lit. f) „,notyfikujące państwo członkowskie zapewnia dostępność uwierzytelniania online, tak aby każda strona ufająca mająca siedzibę na terytorium innego państwa członkowskiego mogła potwierdzić dane identyfikujące osobę otrzymane w postaci elektronicznej. W odniesieniu do stron ufających innych niż podmioty sektora publicznego notyfikujące państwo członkowskie może określić warunki dostępu do tego uwierzytelnienia. [...] Państwa członkowskie nie nakładają żadnych specjalnych niewspółmiernych wymogów technicznych na strony ufające, które zamierzają dokonać takiego uwierzytelnienia, w przypadku gdyby takie wymogi miały uniemożliwić lub znacznie utrudnić interoperacyjność notyfikowanych systemów identyfikacji elektronicznej”.

29 Zgodnie z art. 7 lit. e) „strona wydająca środek identyfikacji elektronicznej zobowiązana jest zapewnić, aby środek identyfikacji elektronicznej był przyporządkowany danej osobie zgodnie z technicznymi specyfikacjami, standardami i procedurami dotyczącymi odpowiedniego poziomu bezpieczeństwa". 


\section{USŁUGI ZAUFANIA}

Drugim niezwykle istotnym obszarem regulacji rozporządzenia eIDAS są tzw. usługi zaufania (ang. trust services) ${ }^{30}$. Ponownie warto podkreślić, że rozporządzenie eIDAS w przeciwieństwie do dyrektywy 99/93 reguluje całą gamę usług zaufania online (a nie jedynie podpis elektroniczny). Celem poszerzenia zakresu regulowanych usług zaufania jest przede wszystkim umocnienie bezpieczeństwa transakcji dokonywanych przez Internet. Zadaniem rozporządzenia eIDAS jest również ujednolicenie ram prawnych świadczenia usług zaufania oraz nadzoru nad ich dostawcami. Należy jednak podkreślić, że wymogi określone w rozporządzeniu będą musiały spełniać jedynie usługi zaufania świadczone na rzecz społeczeństwa, mające skutki dla stron trzecich (z wyłączeniem usług wykorzystywanych w obrębie systemów zamkniętych lub systemów utworzonych w przedsiębiorstwach lub organach administracji publicznej w celu zarządzania procedurami).

Rozporządzenie eIDAS zakreśla ramy prawne dla takich usług zaufania, jak: podpisy elektroniczne ${ }^{31}$, pieczęcie elektroniczne ${ }^{32}$, elektroniczne znaczniki czasu $^{33}$, usługi rejestrowanego doręczenia elektronicznego ${ }^{34}$ i uwierzytelnianie witryn internetowych ${ }^{35}$. Z uwagi na tempo zmian technologicznych we współczesnym świecie w rozporządzeniu przyjęto podejście otwarte na innowacje, tym samym państwa członkowskie zachowały swobodę określania innych rodzajów usług zaufania niż te, które figurują w zamkniętym wykazie przewidzianym w roz-

${ }^{30}$ Usługi zaufania definiuje przepis art. 3 pkt 16 rozporządzenia.

31 „Podpis elektroniczny” oznacza dane w postaci elektronicznej, które są dołączone lub logicznie powiązane z innymi danymi w postaci elektronicznej, i które użyte są przez podpisującego jako podpis (art. 3 pkt 10 rozporządzenia). $Z$ podpisu elektronicznego mogą korzystać tylko osoby fizyczne (z wyłączeniem osób prawnych i innych jednostek organizacyjnych).

32 „Pieczęć elektroniczna” oznacza dane w postaci elektronicznej dodane do innych danych w postaci elektronicznej lub logicznie z nimi powiązane, aby zapewnić autentyczność pochodzenia oraz integralność powiązanych danych (art. 3 pkt 25 rozporządzenia). Pieczęcie elektroniczne służą uwierzytelnianiu dokumentów i zasobów cyfrowych przez osoby prawne. Złożenie pieczęci elektronicznej przez daną osobę prawną jest dowodem wydania dokumentu elektronicznego przez konkretną osobę prawną, a także zapewnieniem pewności pochodzenia i integralności tego dokumentu.

33 „Elektroniczny znacznik czasu” oznacza dane w postaci elektronicznej, które wiążą inne dane w postaci elektronicznej z określonym czasem, stanowiąc dowód na to, że te inne dane istniały w danym czasie (art. 3 pkt 33 rozporządzenia).

34 „Usługa rejestrowanego doręczenia elektronicznego” oznacza usługę umożliwiającą przesłanie danych między stronami trzecimi drogą elektroniczną i zapewniającą dowody związane z posługiwaniem się przesyłanymi danymi, w tym dowód wysłania i otrzymania danych, oraz chroniącą przesyłane dane przed ryzykiem utraty, kradzieży, uszkodzenia lub jakiejkolwiek nieupoważnionej zmiany (art. 3 pkt 36 rozporządzenia).

35 „Certyfikat uwierzytelniania witryn internetowych” oznacza poświadczenie, które umożliwia uwierzytelnianie witryn internetowych i przyporządkowuje witrynę internetową do osoby fizycznej lub prawnej, której wydano certyfikat (art. 3 pkt 38 rozporządzenia). 
porządzeniu, do celów uznania ich na szczeblu krajowym jako kwalifikowanych usług zaufania.

Począwszy od dnia 1 lipca 2016 roku, na terytorium całej Unii Europejskiej obowiązywać zacznie zasada wzajemnej uznawalności zaawansowanych i kwalifikowanych podpisów elektronicznych (art. 27 rozporządzenia) oraz pieczęci elektronicznych (art. 37 rozporządzenia). Pojęcie ,zaawansowanego podpisu elektronicznego" funkcjonowało już w oparciu o regulację dyrektywy $99 / 93^{36}$, wydaje się jednak, że wymagania zawarte w rozporządzeniu są nieco mniej rygorystycz$\mathrm{ne}^{37}$. Zgodnie z brzmieniem art. 26 rozporządzenia eIDAS zaawansowany podpis elektroniczny musi spełniać koniunktywnie cztery przesłanki: ma być unikalnie przyporządkowany podpisującemu, umożliwiać ustalenie jego tożsamości, być składany przy użyciu danych służących do składania podpisu elektronicznego, których podpisujący może — z dużą dozą pewności — użyć pod swoją wyłączną kontrolą oraz być powiązanym z danymi podpisanymi w taki sposób, że każda późniejsza zmiana danych będzie rozpoznawalna ${ }^{38}$.

Dyrektywa 99/93 nie posługiwała się sformułowaniem „kwalifikowany podpis elektroniczny", rozporządzenie definiuje go zaś jako zaawansowany podpis elektroniczny, który jest składany za pomocą kwalifikowanego urządzenia do składania podpisu elektronicznego i który opiera się na kwalifikowanym certyfikacie podpisu elektronicznego ${ }^{39}$. Rozporządzenie, po pierwsze, wprowadza równoważność skutku prawnego kwalifikowanego podpisu elektronicznego z podpisem własnoręcznym $^{40}$, a po drugie stwierdza, że kwalifikowany podpis elektroniczny oparty na kwalifikowanym certyfikacie wydanym w jednym państwie członkowskim ma obowiązek być uznawany za kwalifikowany podpis elektroniczny we wszystkich pozostałych państwach członkowskich ${ }^{41}$. W odniesieniu do wszelkich podpisów

36 Art. 2 pkt 2 dyrektywy 99/93.

37 J. Schroers, B. van Alsenoy, C. Cuijpers, Legal analysis of eSignature services, s. 20, http:// www.futureid.eu/data/deliverables/year3/Public/FutureID_D33.06_WP33_v1.0_Legal_analysis _ eSign_service.pdf (dostęp: 20.03.2016).

$\overline{38}$ Wydaje się, że w polskim porządku prawnym wymagania te spełnia profil zaufany na platformie ePUAP.

39 Art. 3 pkt 12 rozporządzenia.

40 Chociaż zgodnie z zamierzeniem ustawodawcy unijnego rozporządzenie eIDAS nie ma oddziaływać na prawo krajowe ani unijne związane z zawieraniem i ważnością umów lub innych zobowiązań prawnych, lub proceduralnych, dotyczące ich formy (art. 2 ust. 3 rozporządzenia), to regulacja skutku prawnego kwalifikowanego podpisu elektronicznego wydaje się mieć wpływ na prawo polskie. Możliwa jest bowiem taka interpretacja art. 25 ust. 2 rozporządzenia, zgodnie z którą dopuszczalne jest zastępowanie podpisu własnoręcznego kwalifikowanym podpisem elektronicznym. Oznaczałoby to, że od dnia 1 lipca 2016 r. wszędzie tam, gdzie przepis prawa krajowego wymagał będzie złożenia podpisu własnoręcznego, każdy w Unii Europejskiej uprawniony będzie do posłużenia się kwalifikowanym podpisem elektronicznym zamiast własnoręcznym, wywołując przy tym dokładnie ten sam skutek prawny.

${ }^{41}$ Art. 25 ust. 3 rozporządzenia. Dyrektywa 99/93 nie przewidywała takiego obowiązku państw członkowskich Unii Europejskiej. 
elektronicznych rozporządzenie podtrzymuje obowiązującą już wcześniej zasa$\mathrm{dę}^{42}$, że podpisowi elektronicznemu nie można odmówić skutku prawnego ani dopuszczalności jako dowodu w postępowaniu sądowym wyłącznie z tego powodu, że podpis ten ma postać elektroniczną lub że nie spełnia wymogów dla kwalifikowanych podpisów elektronicznych (art. 25 ust. 1 rozporządzenia). Podkreślić w tym miejscu należy jednak, że systemy prawne państw członkowskich mogą definiować inne, dalsze skutki podpisów elektronicznych. Analogiczne przepisy dotyczące pieczęci elektronicznej zawierają przepisy art. 35 i n. rozporządzenia.

W odniesieniu do dwóch dalszych usług zaufania (elektronicznych znaczników czasu oraz usług rejestrowanego doręczenia elektronicznego) rozporządzenie eIDAS poprzestaje na zakazie kwestionowania ich skutku prawnego, zagwarantowaniu ich wartości dowodowej oraz stworzeniu domniemań z nimi związanych $^{43}$. W przypadku kwalifikowanego elektronicznego znacznika czasu art. 41 ust. 3 rozporządzenia wprowadza również zasadę wzajemnej uznawalności we wszystkich państwach członkowskich UE. W odniesieniu zaś do certyfikatów uwierzytelniania witryn internetowych ustawodawca unijny nie zdecydował się ani na definiowanie ich skutku prawnego, ani nakazanie przydawania im wartości dowodowej, ograniczając się do wskazania, jakie wymogi spełniać muszą kwalifikowane certyfikaty uwierzytelniania witryn ${ }^{44}$.

Celem, który przyświecał ustawodawcy unijnemu w trakcie prac nad rozporządzeniem eIDAS, było wsparcie powszechnego, transgranicznego korzystania z usług zaufania na terytorium całej Unii Europejskiej. Aby możliwe było realizowanie tego planu, nieodzowne stało się zapewnienie możliwości wykorzystywania tych usług jako dowodu w postępowaniach sądowych we wszystkich państwach członkowskich. Istotną nowością w rozporządzeniu eIDAS jest wprowadzenie na potrzeby powyższego celu definicji dokumentu elektronicznego, który zgodnie z brzmieniem art. 3 pkt 35 rozporządzenia oznacza każdą treść przechowywaną w postaci elektronicznej, w szczególności tekst lub nagranie dźwiękowe — wizualne lub audiowizualne ${ }^{45}$. Rozporządzenie eIDAS zawiera bezwzględny zakaz kwestionowania skutku prawnego dokumentu elektronicznego lub jego dopuszczalno-

42 Por. art. 5 ust. 2 dyrektywy 99/93.

43 Art. 41 oraz art. 43 rozporządzenia.

44 Art. 45 rozporządzenia.

45 Warto w tym miejscu nadmienić, że definicja ta nie pokrywa się z definicją dokumentu, która od dnia 8 września 2016 r. (tj. od dnia wejścia w życie ustawy z dnia 10 lipca 2015 r. o zmianie ustawy — Kodeks cywilny, ustawy — Kodeks postępowania cywilnego oraz niektórych innych ustaw; Dz.U. 2015, poz. 1311) obowiązywać będzie w prawie polskim. Zgodnie z oczekującym na wejście w życie przepisem art. $77^{3}$ ustawy z dnia 23 kwietnia 1964 r. — Kodeks cywilny (Dz.U. 2014, poz. 121 ze zm.) „,dokument” definiowany jest jako nośnik informacji umożliwiający zapoznanie się z jej treścią. Ustawodawca polski przy definiowaniu pojęcia „dokument” położył więc nacisk na nośnik, a nie na informację na tym nośniku zawartą. Ustawodawca unijny zdefiniował zaś dokument elektroniczny właśnie jako treść intelektualną zawartą na nośniku elektronicznym. Należy przy tym podkreślić, że rozporządzenie jest aktem prawnym, który obowiązuje bezpośrednio na terytorium 
ści jako dowodu w postępowaniu sądowym wyłącznie z tego powodu, że dokument ten ma postać elektroniczną. Mimo że przepisy dyrektywy 99/93 zawierały bardzo podobnie brzmiące uregulowanie ${ }^{46}$, sądy niektórych państw członkowskich Unii Europejskiej (w tym sądy polskie) mimo obowiązku implementacji dyrektywy nie uznawały lub uznawały niechętnie dokumenty elektronicznie w postępowaniach sądowych ${ }^{47}$.

\section{DOSTAWCY USŁUG ZAUFANIA}

Celem rozporządzenia eIDAS jest zapewnienie wysokiego poziomu bezpieczeństwa korzystania z usług zaufania. Świadczenie tego typu usług elektronicznych powinno więc spełniać wymogi przejrzystości i należytej staranności podmiotów za te usługi odpowiedzialnych (tzw. dostawców usług zaufania). Z uwagi na rodzaj świadczonych przez nie usług rozporządzenie eIDAS wprowadza podział na kwalifikowanych i niekwalifikowanych dostawców usług zaufania. Dostawcą kwalifikowanym dany podmiot może stać się dopiero wtedy, gdy status taki nada mu odpowiedni organ nadzoru ${ }^{48}$. Jeżeli tak się stanie, będzie on uprawniony do świadczenia kwalifikowanych usług zaufania (np. kwalifikowanych podpisów elektronicznych czy kwalifikowanych pieczęci elektronicznych).

W celu zapewnienia należytej ochrony użytkowników usług zaufania oraz poprawnego funkcjonowania rynku wewnętrznego państwom członkowskim powierzone zostało zadanie wyznaczenia odpowiedniego organu nadzorczego, który będzie odpowiedzialny za sprawowanie nadzoru nad dostawcami usług zaufania ${ }^{49}$.

całej Unii Europejskiej, bez konieczności transpozycji zawartych w nim przepisów na grunt prawa krajowego, a w przypadku kolizji z przepisami krajowymi ma przed nimi pierwszeństwo.

46 Zob. art. 5 ust. 2 dyrektywy 99/93 stanowiący, że państwa członkowskie mają obowiązek zapewnić, żeby nie odmawiano podpisowi elektronicznemu skuteczności prawnej i dopuszczalności jako dowodu w postępowaniu sądowym jedynie dlatego, że jest $w$ formie elektronicznej lub nie jest oparty na kwalifikowanym certyfikacie, lub nie jest oparty na kwalifikowanym certyfikacie pochodzącym od akredytowanego podmiotu świadczącego usługi certyfikacyjne, lub nie jest złożony za pomocą bezpiecznego urządzenia służącego do składania podpisu.

47 P.P. Polański, op. cit., s. 776-777. Autor jako przykład takiego zachowania sądów krajów członkowskich wskazuje stanowisko polskiego Sądu Najwyższego, który uznał, że „pismo procesowe wniesione w postaci elektronicznej — w zakresie nieunormowanym szczególnymi przepisami — nie wywołuje skutków prawnych, które ustawa wiąże ze złożeniem pisma procesowego, przy czym nie chodzi o brak formalny pisma, lecz o jego pierwotny, nieusuwalny brak skuteczności spowodowany użyciem nieautoryzowanej techniki" (Uchwała Sądu Najwyższego — Izba Cywilna z dnia 23 maja 2012 r., sygn. akt III CZP 9/12, Legalis nr 468019).

48 Procedura nadawania statusu kwalifikowanego dostawcy zaufania odpisana została w art. 21 rozporządzenia.

49 Aby ułatwić nadzór nad kwalifikowanymi dostawcami usług zaufania (np. w sytuacji, gdy dostawca świadczy swoje usługi na terytorium innego państwa członkowskiego i nie podlega tam nadzorowi), rozporządzenie eIDAS przewiduje stworzenie systemu wzajemnej pomocy między 
Nadzór ten będzie więc sprawowany co do zasady jedynie na poziomie krajowym, a katalog sankcji mających zastosowanie w przypadku naruszeń rozporządzenia stworzą samodzielnie państwa członkowskie Unii Europejskiej (art. 16 rozporządzenia $)^{50}$. Celem działań nadzorczych każdorazowo pozostawać będzie zapewnienie spełniania przez wszystkich dostawców (oraz świadczonych przez nich usług zaufania) wymogów przewidzianych w rozporządzeniu. W stosunku do kwalifikowanych dostawców usług zaufania przewidziane zostały surowsze wymagania w zakresie nadzoru — organ nadzoru uprawniony będzie do podejmowania działań nadzorczych zarówno ex ante, jak i ex post. W stosunku zaś do dostawców niekwalifikowanych organ nadzorczy uprawniony będzie do sprawowania nadzoru tylko w razie konieczności i jedynie przez działania nadzorcze ex post (tzn. dopiero wtedy, gdy niekwalifikowany dostawca podejrzewany będzie o uchybienie). Niekwalifikowani dostawcy z uwagi na charakter świadczonych przez siebie usług podlegać więc będą łagodniejszym formom nadzoru. Co więcej, organ nadzorczy nie będzie miał ogólnego obowiązku nadzorowania tych podmiotów; powinien on podejmować działania nadzorcze jedynie wtedy, gdy zostanie poinformowany (np. przez samego dostawcę, inny organ nadzoru, w drodze zgłoszenia od użytkownika albo na podstawie własnego dochodzenia), że niekwalifikowany dostawca usług zaufania nie wypełnia wymogów rozporządzenia eIDAS.

Dostawcy usług zaufania oprócz działań nadzorczych podlegają dodatkowo obowiązkowi zgłaszania przypadków naruszenia bezpieczeństwa (art. 19 rozporządzenia), obowiązkowi weryfikacji tożsamości podmiotu, któremu wydawany jest kwalifikowany certyfikat (art. 24 rozporządzenia), a także audytom (art. 20 rozporządzenia). Kwalifikowani dostawcy usług zaufania mają obowiązek poddania się (co najmniej raz na dwa lata) prowadzonemu na ich koszt audytowi mającemu na celu ustalenie, czy spełniają oni standardy określone w rozporządzeniu. Powstały w ten sposób raport z oceny zgodności są oni zobowiązani przedłożyć organowi nadzoru w ciągu trzech dni roboczych od jego otrzymania. Bez uszczerbku dla powyższego obowiązku organ nadzoru może również w dowolnym momencie przeprowadzić audyt lub zwrócić się do jednostki oceniającej zgodność o przeprowadzenie oceny zgodności w stosunku do danego kwalifikowanego dostawcy usług zaufania (również na jego koszt). Niewyeliminowanie przez kwalifikowanego dostawcę przypadków niespełniania wymogów określonych w rozporządzeniu (w zależności od ich wielkości, czasu trwania i skutków) może doprowadzić nawet do odebrania dostawcy lub jego usłudze statusu kwalifikowanego ${ }^{51}$.

organami nadzoru w różnych państwach członkowskich (zob. art. 18 oraz motyw 42 preambuły rozporządzenia).

50 W tym miejscu warto zauważyć, że przepisy rozporządzenia eIDAS przewidują możliwość nadzoru jedynie co do usług zaufania, lecz już nie co do identyfikacji elektronicznej (C. Cuijpers, J. Schroers, op. cit., s. 9).

51 Art. 20 ust. 3 rozporządzenia. 
Ustawodawca unijny przewidział również możliwość poniesienia przez dostawcę usług zaufania odpowiedzialności odszkodowawczej. Dostawcy usług zaufania są bowiem odpowiedzialni za szkody wyrządzone osobie fizycznej lub prawnej w związku z niewypełnieniem obowiązków nałożonych na nich na mocy rozporządzenia (niezależnie od tego, czy doszło do tego w sposób zamierzony, czy z powodu zaniedbania). Tak samo jak w przypadku odpowiedzialności za niewypełnienie obowiązków związanych z e-identyfikacją, do przypisania odpowiedzialności sądy państw członkowskich stosować będą krajowe przepisy w tym zakresie, z tą jednak różnicą, że w przypadku niekwalifikowanych dostawców usług zaufania ciężar dowiedzenia zamiaru lub zaniedbania dostawcy spoczywać będzie na poszkodowanym, a w przypadku kwalifikowanych dostawców rozporządzenie eIDAS wprowadza domniemanie dotyczące istnienia tegoż zamiaru lub zaniedbania, co znacząco ułatwia sytuację procesową poszkodowanego. Podkreślić w tym miejscu należy, że wszyscy dostawcy usług zaufania mają obowiązek przyjmować odpowiednie środki techniczne i organizacyjne ${ }^{52} \mathrm{w}$ celu zarządzania ryzykiem, na jakie narażone jest bezpieczeństwo świadczonych przez nich usług zaufania, a kwalifikowani dostawcy są dodatkowo zobowiązani — w odniesieniu do ryzyka związanego z pociągnięciem ich do odpowiedzialności odszkodowawczej — do utrzymywania dostatecznych zasobów finansowych i dysponowania stosowanym ubezpieczeniem od odpowiedzialności zgodnie z prawem krajowym ${ }^{53}$.

Państwom członkowskim Unii Europejskiej powierzone zostało prowadzenie i publikowanie tzw. zaufanych list (ang. trusted lists) zawierających informacje dotyczące kwalifikowanych dostawców usług zaufania, za które dane państwo jest odpowiedzialne, wraz z informacjami na temat świadczonych przez nich kwalifikowanych usług zaufania. $Z$ uwagi na to, że zaufanie do usług online jest niezbędnym elementem powszechności korzystania z nich, rozporządzenie eIDAS wprowadziło nowy, dobrowolny, unijny znak zaufania służący oznaczaniu kwalifikowanych usług zaufania. Dzięki niemu możliwe będzie wyraźne odróżnienie usług kwalifikowanych od pozostałych usług zaufania, a do użytkowników usług kwalifikowanych trafi w ten sposób jasna, prosta i łatwo rozpoznawalna informacja o gwarancji bezpieczeństwa i jakości świadczonych usług.

\section{PODSUMOWANIE}

Identyfikacja elektroniczna znajduje się na drodze intensywnych przemian. Rozporządzenie eIDAS stanowi ważny element tej ewolucji, a zarazem kolejny krok w budowaniu rynku cyfrowego Unii Europejskiej. Uregulowanie nowych,

52 Rozporządzenie nie doprecyzowuje tych środków, lecz jedynie zakreśla wytyczne w tym zakresie (P.P. Polański, op. cit., s. 779). Środki te powinny być współmierne do stopnia ryzyka.

53 Art. 24 ust. 2 lit. c) rozporządzenia. 
transgranicznych usług zaufania oraz zapewnienie interoperacyjności systemów identyfikacji elektronicznej we wszystkich państwach członkowskich powinno doprowadzić do zwiększania zaufania i szerszego zastosowania komunikacji elektronicznej zarówno wśród obywateli Unii Europejskiej, jak i w organach administracji publicznej krajów członkowskich. Przychylnie należy odnieść się do umocnienia znaczenia usług zaufania, poszerzenia ich zakresu, wprowadzenia wyraźnego obowiązku ich wzajemnego uznawania, a także przejrzystego zróżnicowania rynku w tym zakresie (w szczególności odróżnienia usług i usługodawców kwalifikowanych). Na pochwałę zasługuje fakt, że rozwiązania rozporządzenia skonstruowane zostały tak, aby upowszechnić internetową aktywność obywateli, przedsiębiorców i organów władzy publicznej w Unii Europejskiej oraz uczynić ją możliwie bezpieczną. Trudno jednak jednoznacznie przewidzieć, czy rozwiązania te trafnie wpasują się w potrzeby wskazanych podmiotów.

Rozporządzenie eIDAS daje wiele narzędzi zarówno w zakresie e-identyfikacji, jak i usług zaufania, co daje nadzieję na zintensyfikowanie wzrostu gospodarczego generowanego przez europejską gospodarkę cyfrową. Pamiętać należy jednak, że to od woli obywateli Unii Europejskiej, a w szczególności gotowości organów władzy publicznej zależeć będzie powszechność zastosowania rozwiązań w zakresie e-identyfikacji i usług zaufania, a tym samym sukces samego rozporządzenia.

\section{EIDAS REGULATION - A NEW LEGAL FRAMEWORK FOR ELECTRONIC IDENTIFICATION AND TRUST SERVICES IN THE EUROPEAN UNION}

\section{Summary}

This article analyses the Electronic Identification and Trust Services (eIDAS) Regulation which per 1 July 2016 will create a new European legal framework for secure electronic interactions across the European Union (EU). The eIDAS Regulation seeks to enhance trust in electronic transactions in the internal EU market by providing a common foundation for secure electronic interactions between citizens, businesses and public authorities, thereby increasing the effectiveness of public and private online services. The article reviews provisions of the eIDAS Regulation related to electronic identification (eID), such as removal of existing barriers to the use of the eID in the EU, mutual eID recognition by the EU member states, and interoperability of all national eID schemes. Furthermore, the article focuses on trust services and service providers. Comparing the eIDAS Regulation with its predecessor, the eSignature Directive, the article outlines advantages of the eIDAS Regulation related to the possibility of using trust services as evidence in legal proceedings. 